\title{
ДОСЛІДЖЕННЯ МОЖЛИВОСТЕЙ МЕТОДУ ПОЛІНОМІАЛЬНОЇ АПРОКСИМАЦІї ДЛЯ ВИЯВЛЕННЯ ГЕНДЕРНИХ ВІДМІННОСТЕЙ НА ST-Т IНTЕРВАЛІ ЕКГ
}

\author{
О. О. Заярна' ${ }^{1}$, Ю. О. Фролов ${ }^{2}$, М. М. Будник ${ }^{1,2}$, І. А. Чайковський ${ }^{2}$ \\ Київський національний університет імені Тараса Шевченка \\ Інститут кібернетики імені В.М. Глушкова НАН України
}

\begin{abstract}
Разработан и программно реализован алгоритм аппроксимации ЭКГ сигнала. Представлены результаты полиномиальной аппроксимации на интервале ST-T. Найдено оптимальную степень полинома, диагностические параметры групп здоровых мужчин и женщин.
\end{abstract}

3 метою автоматизації процесу спостереження даних ЕКГ, розрізнення морфології, фільтрації тощо протягом останніх десятиріч з середини ХХ століття були проведені дослідження щодо параметризації ЕКГ. В роботах $[1,2]$ було розглянуто проблеми параметризації ЕКГ з використанням рядів Фур'є та параметризацію функціями Лагера [3] і виявлено спільний суттєвий недолік - недостатня точність параметризації при виправданій кількості параметрів. В роботі [4] розглянуто розбиття ЕКГ-циклу на інтервали та розкладання кожного циклу в ряди Фур' $€$, але спосіб дає недостатню точність параметризації 1618 параметрів для досягання точності апроксимації $2 \%$. Апроксимація гаусовими імпульсами та кускове задання ЕКГ-інтервалу в роботі [5] показано, що для достатньої точності необхідно 3-5 імпульсів, тобто до 20 параметрів, що є суттєвим недоліком. Виходячи з розглянутих способів в даній роботі було обрано параметризацію на основі апроксимації поліномами методом найменших квадратів, оскільки доцільність методу не може вважатися вивченою та дослідженою.

Метою роботи $€$ відшукання інформативних параметрів для діагностики кардіологічних захворювань на основі поліноміальної апроксимації ST-Т інтервалу ЕКГ та дослідження наявності гендерної різниці між чоловіками та жінками.

Матеріали та методи дослідження. Проводилося обстеження клінічно здорових осіб та запис ЕКГ сигналу, за допомогою електрокардіографа з 16-розрядним АЦП, в кожному з 12 стандартних відведень. Вихідні дані були отримані у вигляді бінарних файлів ЕКГ обстеження здорової людини (групи пацієнтів). В якості вхідних даних для досліджень слугували дані, викладені на сайті Німецького національного інституту метрологіï (Physikalisch-Technische Bundesanstalt, PTВ)[5], що базувалися на обстеженнях, виконаних Берлінською кардіологічною клінікою імені Бенджаміна Франкліна. База даних РТВ викладена у вільному доступі та складається з 549 ЕКГ досліджень 294 паціснтів. Була розроблена програма-конвертер, яка перетворювала бінарні файли у текстові. Програма викладена у вільному доступі та не потребує додаткового опису. Дані з бази були розділені на групи залежно від статі.

Методика. 1. Конвертувати файли ЕКГ з бінарного в текстовий формат.

2. Переконвертовані текстові файли розділити на групи залежно від статі.

3. Виділити ST-Т інтервали для кожного пацієнта 3 відповідної групи в програмі SCPExtractor.

4. Внормувати та усереднити вибірки клінічно здорових чоловіків та жінок в програмному пакеті Exel.

5. Створити три текстові файли, до яких занести усереднені дані для трьох груп: жінки, чоловіки та всі обстежені разом.

6. Апроксимувати отримані дані поліномами різних ступенів за допомогою програми Phantasiia.

7. Побудувати залежності нормованого СКВ апроксимації від ступеня апроксимуючого полінома для всіх груп.

8. Отримати набір інформативних параметрів.

Програмна реалізація. Виділення ST-T інтервалів для кожної обстеженої людини відбувалось в програмі SCPExtractor, яку реалізовано в програмному середовищі Delphi7. Робоче вікно програми наведено на рисунку 1. Програма дає можливість завантаження даних з файлу, масштабування зображення сигналу для полегшення сприйняття оператором, можливість виділення ST-T інтервалу оператором, можливість бачити у відповідному вікні загальні відомості пацієнта, збереження всіх результатів, обчислених в автоматичному режимі, в окремий файл (та окремо зберігається сам ST-T інтервал).

Потім апроксимували отримані дані поліномами різних ступенів за допомогою програми Phantasiia, po- 
Puc. 1. Вікно програми SCPExtractor.

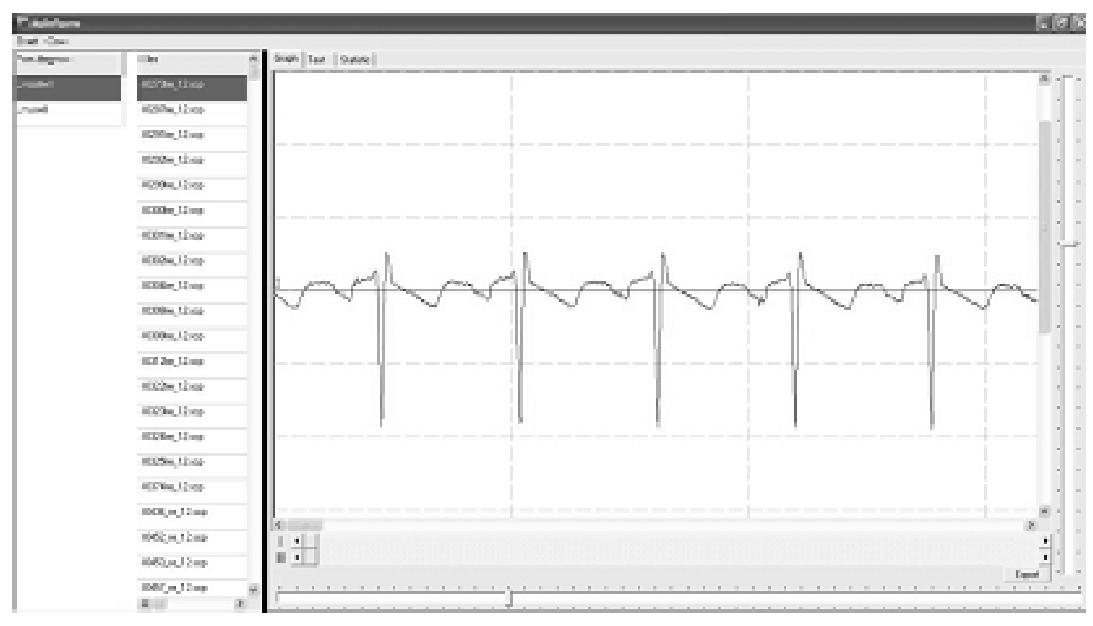

боче вікно якої зображене на рисунку 2. Після апроксимації дані зберігаються у файл. У файлі (SAVEs.xls) записуються (дописуються) назва відкритого файлу, значення початку та кінця виділеного 3 кардіограми

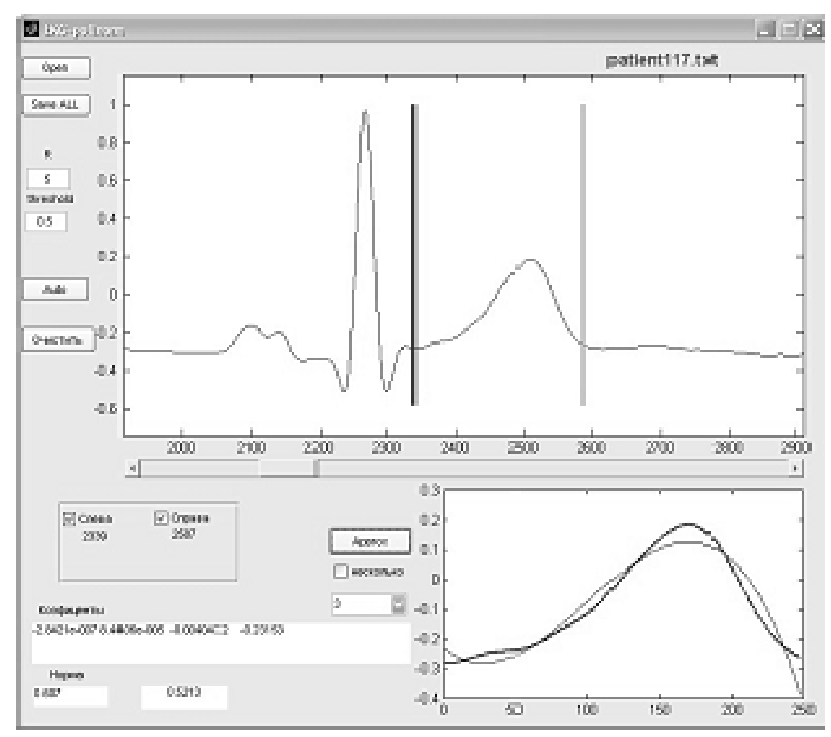

Puc. 2. Робоче вікно програми Phantasiia.
ST-T інтервалу, коефіцієнти апроксимації та показники точності апроксимації для поліномів ступенів від 0 до 10 включно. Також вказано квадратичне відхилення (КВ) апроксимації поліномом кожного ступеня, наведене нормоване на розмах амплітуди ST-T інтервалу та кількість відліків КВ в процентах НСКВ (рис. 3). Подальші рядки таблиці заповнені коефіцієнтами апроксимації відповідно для ступеня доданка. Кількість коефіцієнтів завжди на одиницю більша, ніж показник ступеня полінома. Записуються обидві межі виділеного інтервалу, відраховуючи від початку кардіограми.

Результати й обговорення. В якості критерію точності апроксимації було обране НСКВ, оптимальним прийнятий рівень $-10 \%$. Проаналізувавши отримані дані можна зробити висновок, що достатню точність апроксимації для групи жінок має апроксимуючий поліном ступеня не менше ніж 6, для чоловіків та всієї групи здорових - не нижче 7 ступеня. Було встановлено, що інформативними параметрами для 3 груп здорових, отриманих на основі апроксимації, $€$ коефіцієнти при цих поліномах (табл. 1).

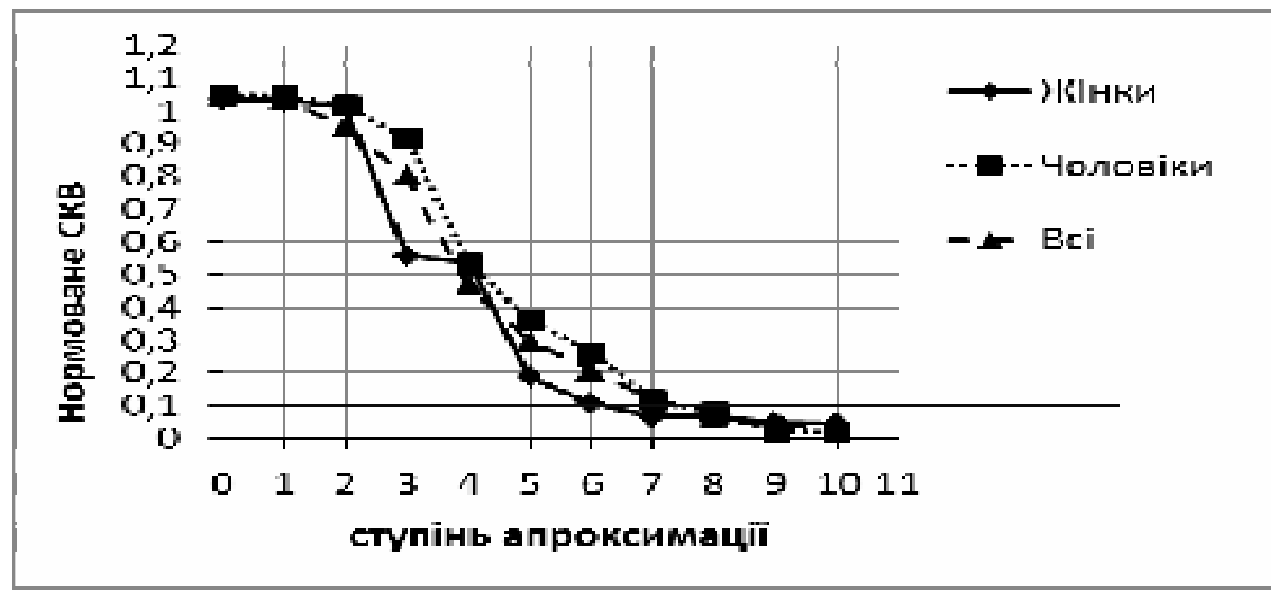

Puc. 3. Залежність точності апроксимації від ступеня апроксимуючого полінома. 
Таблиця 1. Набір значень інформативних параметрів - коефіцієнтів полінома для трьох груп пацієнтів

\begin{tabular}{|c|c|c|c|}
\hline & Жінки & Чоловіки & Всі \\
\hline $\mathrm{A}_{0}$ & $-3,40 \mathrm{E}-02$ & $-6,70 \mathrm{E}-03$ & $-2,76 \mathrm{E}-02$ \\
\hline $\mathrm{A}_{1}$ & $7,64 \mathrm{E}-03$ & $-1,89 \mathrm{E}-03$ & $8,43 \mathrm{E}-03$ \\
\hline $\mathrm{A}_{2}$ & $-6,28 \mathrm{E}-05$ & $1,23 \mathrm{E}-03$ & $3,15 \mathrm{E}-04$ \\
\hline $\mathrm{A}_{3}$ & $-3,05 \mathrm{E}-06$ & $-5,71 \mathrm{E}-05$ & $-2,38 \mathrm{E}-05$ \\
\hline $\mathrm{A}_{4}$ & $1,14 \mathrm{E}-07$ & $1,23 \mathrm{E}-06$ & $6,32 \mathrm{E}-07$ \\
\hline $\mathrm{A}_{5}$ & $-1,03 \mathrm{E}-09$ & $-1,29 \mathrm{E}-08$ & $-7,20 \mathrm{E}-09$ \\
\hline $\mathrm{A}_{6}$ & $2,77 \mathrm{E}-12$ & $6,30 \mathrm{E}-11$ & $3,65 \mathrm{E}-11$ \\
\hline $\mathrm{A}_{7}$ & & $-1,17 \mathrm{E}-13$ & $-6,81 \mathrm{E}-14$ \\
\hline
\end{tabular}

Висновки. 1. Створено комп'ютерну програму, яка дозволяє візуалізувати ЕКГ сигнал, імпортувати файли з масиву даних та виділяти інтервал кардіоциклу 3 подальшим збереженням даних у текстовий файл.

2. Оброблено (конвертовано, усереднено та апроксимовано поліноміальними функціями різних ступенів) файли з записами ST-T інтервалів 68 здорових

\section{Література}

1. Berson A. S. Computer Analysis of the Electrocardiogram/ Berson A. S. Pipberger H. V.//Engeniring. - Baltimor, 1967.

2. Cady L. D. A method for Electrocardiogram / Cady L. D., Woodbury M. A. // Wave Pattern Estimation, 1967.

3. Слепян Л. В. Труды Института физиологии им. И.Бериташвили. - Т. 6, Тбилиси, 1945. пацієнтів: жінок, чоловіків і всіх здорових разом.

3. Знайдено інформативні показники для всіх трьох груп - це коефіцієнти апроксимантів, для жінок 7 коефіцієнтів полінома 6 ступеня, для чоловіків та загальної групи здорових 8 коефіцієнтів полінома 7 ступеня. Знайдено відмінність у формі ST-T інтервалу між чоловіками та жінками.

4. Абрамов М. В. Аппроксимации экспонентами временного кардиологического ряда на основе ЭКГ // Вестник кібернетики. -2009 . - № 9.

5. Режим доступу: http://www.physionet.org/physiobank/ database/ptbdb/. 